\title{
GEOLOGICAL SURVEY OF CANADA RADIOCARBON DATES II
}

\author{
W. DYCK and J. G. FYLES* \\ Geological Survey of Canada, Ottawa, Canada
}

INTRODUCTION

The accompanying date list includes age determinations completed during the period December 1, 1961 to November 1, 1962. All measurements were made with the $2 \mathrm{~L}$ counter described in our first date list (GSC I). Sample preparation, counting procedures, and calculation of dates were as described in GSC I except as outlined below:

a. Base and acid treatments were carried out with $1 \mathrm{~N} \mathrm{HCl}$ and $2 \%$ $\mathrm{NaOH}$ instead of $2 \mathrm{~N} \mathrm{HCl}$ and $4 \% \mathrm{NaOH}$, because the less-concentrated solutions were still strong enough to accomplish the desired purification.

b. The $\mathrm{Mg}\left(\mathrm{ClO}_{4}\right)_{2}$ drying columns were removed from the purification train in order to test their effect, if any, on the purity of the gas. Since there was no detectable change in the purity of the gas these columns were left out of the purification line.

c. Ages were calculated using 0.950 of the activity of the N.B.S. oxalicacid standard as the reference activity and A.D. 1950 as the zero reference year, in line with the recommendations of the editors of Radiocarbon.

In general finite ages were calculated only if the sample activity was greater than four standard deviations. Using the $4 \sigma$ criterion, zero activity in the present system corresponds to an age of $>39,000 \mathrm{yr}$. Thus samples in this date list with ages designated "greater than," yet appreciably below this figure, contained measurable activities which were less than $4 \sigma$.

No corrections for barometric-pressure fluctuations have been applied to the measured activities. The observed barometric-pressure fluctuations of \pm 1.5 $\mathrm{cm}$, and the barometric-pressure effect of $-1.2 \% / \mathrm{cm} \mathrm{Hg}$ would, in the worst possible case, change the calculated age of samples with counting rates near $4 \sigma$ (i.e. ages of ca. $40,000 \mathrm{yr}$ ) by ca. $4 \%$, and by less than $1 \%$ for samples with ages of $30,000 \mathrm{yr}$ and younger. Since the ages of all samples with a finite age above $30,000 \mathrm{yr}$ are arbitrarily quoted with a $2 \sigma$ error, the barometricpressure effect is well covered.

A 10-pen Esterline-Angus Operation-Event recorder is being used to record continuously the counting rates of the various channels. Signals from specific decatron outputs are fed into univibrator-type circuits which then actuate a relay-driven pen mechanism. The recording consists of blips made by the pens on a chart that moves at constant known speed. Each blip represents $10^{\mathrm{n}}$ counts where $\mathrm{n}=1,2,3, \ldots$ etc., corresponding to the 1 st, $2 \mathrm{nd}, 3 \mathrm{rd} \ldots$ etc. decatron output which is selected as desired, depending on the counting rate of the particular channel. Thus large counting-rate fluctuations due to electrical and/or atmospheric disturbances can be detected at a glance.

\footnotetext{
* The introductory part of this paper has been prepared by the first author, who operates the laboratory. The date list has been compiled by the second author from descriptions of samples and interpretations of dates by the various collectors.
} 
The background of the $2 \mathrm{~L}$ counter operating at $2 \mathrm{~atm}$ has remained constant at 1.4 counts $/$ min for 10 months.

A $5 \mathrm{~L}$ copper counter and an all-metal filling line, designed to operate at up to $5 \mathrm{~atm}$, have been constructed. Preliminary tests indicate that background and modern wood counts are 3.0 counts $/ \mathrm{min}$ and $33 \mathrm{counts} / \mathrm{min}$, respectively, at $1 \mathrm{~atm} \mathrm{CO}_{2}$, and that background increases at ca. 1 count $/ \mathrm{min} / \mathrm{atm}$.

\section{SAMPLE DESCRIPTIONS}

I. GEOLOGICAL SAMPLES

\section{A. Eastern Canada}

\section{GSC-56. Grand Falls, New Brunswick}

$9830 \pm 160$

7880 в.c.

Gyttja from borehole in Town of Grand Falls (47 $02.4^{\prime} \mathrm{N}$ Lat, $67^{\circ} 44.5^{\prime}$ W Long), from shelby-tube sample $16 \mathrm{ft}$ to $18 \mathrm{ft}$ below surface (alt $462 \mathrm{ft}$ ). The gyttja is underlain successively by Lake Madawaska clay, till of the Grand Falls drift, and gravel. These deposits fill an old buried channel passing through Grand Falls. Coll. 1961 by H. A. Lee." Comment: date is minimum for the Grand Falls drift (other dates: GSC-18, $9820 \pm 130$, GSC-I; I(GSC)$2,10,220 \pm 350$, Isotopes I), and is older than previous dates for Lake Madawaska clay (W-353, $8250 \pm 200$, USGS IV; L-190B, $8200 \pm 300$, Lamont II) which crop out $\mathrm{N}$ of Grand Falls in the St. John River Valley. In the pollen diagram from this core, prepared by J. Terasmae, the dated sample falls in a zone characterized by a spruce maximum and is assumed to correlate with Deevey's Zone A in Aroostook County, Maine (Deevey, 1951) which Ogden (1959) has correlated with Zone B to the S in Massachusetts and Connecticut. Sample pretreatment did not include the usual NaOH-leach. Sample diluted with dead gas for counting.

\section{GSC-33. Milford Station, Nova Scotia}

Wood from gypsum quarry at Dutch Settlement $2 \mathrm{mi}$ SSE of Milford Station $\left(45^{\circ} 00.5^{\prime} \mathrm{N}\right.$ Lat, $63^{\circ} 25.5^{\prime} \mathrm{W}$ Long). Wood from basal part of till $40-\mathrm{ft}$ thick overlying gypsum (see Prest in Stockwell, 1957, p. 447). O. L. Hughes (oral communication) relates this till to the lower of two till sheets nearby, both of which are inferred to represent a single Wisconsin glaciation (Hughes, 1957). Coll. 1954 by I. M. Stevenson. Comment: wood from the same site has been dated as $>18,000 \mathrm{yr}$ by the Nova Scotia Research Foundation using the solid-carbon method (written communication J. E. Blanchard to V. K. Prest.

\section{GSC-101. Prince Edward Island, W coast $\quad 12,410 \pm 170$}

Marine shells (Mya pseudoarenaria) from sea cliff on $\mathrm{W}$ coast of Prince Edward Island $1 \mathrm{mi} \mathrm{S}$ of Miminegash ( $46^{\circ} 52^{\prime} \mathrm{N}$ Lat, $64^{\circ} 14^{\prime} \mathrm{W}$ Long). Shells collected ca. $30 \mathrm{ft}$ above sealevel from bottom $2 \mathrm{ft}$ of a 5 -ft bed of clean gray sand with a few red-clay laminae near the base, overlying red clayey till. The * All persons referred to as collectors or submittors of samples or cited as sources of data are with the Geological Survey of Canada unless otherwise specified. 
sand is overlain by $5 \mathrm{ft}$ of poorly sorted gravel. It is believed that the sand accumulated when the shore was ca. $50 \mathrm{ft}$ above its present position and that the poorly sorted gravels were winnowed out of till by waves when the shoreline had dropped below alt $45 \mathrm{ft}$. The shells relate to a period of major terracing of the $\mathrm{W}$ coast following deglaciation of the island, whereas the highest marine features, at alt ca. $80 \mathrm{ft}$, originated when the island was still partly ice covered. Coll. 1962 by V. K. Prest. Comment (V.K.P.) : the date provides evidence that ca. 12,500 yr ago the $\mathrm{W}$ coast of Prince Edward Island stood ca. $50 \mathrm{ft}$ lower relative to the sea than at present. Ice retreat from the NW part of the island and initial encroachment of the sea took place somewhat earlier, possibly ca. 13,500 yr ago.

\section{Newfoundland North coast series}

\section{GSC-55. Baie Verte River}

\section{$11,520 \pm 180$ 9570 в.c.}

Marine pelecypod shells (mainly Macoma calcarea, Mya truncata, and Hiatella arctica) from bank of Baie Verte River, Newfoundland, 3.7 mi above river mouth $\left(49^{\circ} 54.5^{\prime} \mathrm{N}\right.$ Lat, $56^{\circ} 17^{\prime} \mathrm{W}$ Long). Shells from dark-colored silty clay extending $4 \mathrm{ft}$ above river and covered by $10 \mathrm{ft}$ of sand and gravel probably of recent stream origin. The shell-bearing silty clay is $160 \mathrm{ft}$ above sealevel and ca. $60 \mathrm{ft}$ higher than any shells previously reported along this coast. Limit of marine submergence in the vicinity is ca. $200 \mathrm{ft}$ above present sealevel; hence the shells should be little younger than the earliest highest marine features. Coll. 1961 by E. P. Henderson. Date based on one weekend count only.

\section{GSC-75. Middle Arm, Green Bay}

$11,950 \pm 170$

$$
10,000 \text { в.c. }
$$

Shells of Hiatella arctica and Mya truncata from alt 35 to $42 \mathrm{ft}$ in wall of a gully adjacent to $\mathrm{N}$ shore of Middle Arm, Green Bay, Newfoundland $\left(49^{\circ}\right.$ $42^{\prime} \mathrm{N}$ Lat, $56^{\circ} 06^{\prime} \mathrm{W}$ Long), ca. $20 \mathrm{mi}$ SE of GSC-55. The large thick shells are from bouldery, till-like material that probably is glacio-marine. Hence the shells are believed to relate to the initial influx of the sea during glacial retreat. Coll. 1961 by E. P. Henderson.

\section{GSC-87. Southwest Arm, Green Bay}

$11,880 \pm 190$ 9930 в.C.

Marine pelecypod-, gastropod-, and barnacle shells and shell fragments from bank of Paddy's Brook, 1 mi upstream from head of Southwest Arm, Green Bay, Newfoundland $\left(49^{\circ} 35^{\prime} \mathrm{N}\right.$ Lat, $56^{\circ} 12^{\prime} \mathrm{W}$ Long). Shells from silty clay at stream level $6 \mathrm{ft}$ below top of bank and $40 \mathrm{ft}$ above sealevel. The clay forms the bottomset beds of a marine delta. The top of the delta at alt $180 \mathrm{ft}$ probably represents the limit of marine submergence in the vicinity, as the delta was largely constructed of outwash from the melting ice. The shells should date the early part of the interval of marine submergence when glacial ice was withdrawing from the area. Coll. 1961 by E. P. Henderson.

General comment: these three dates seem to indicate that the ice withdrew from the $\mathrm{N}$ coast of Newfoundland ca. 12,000 yr ago. The dates are considerably older than other dates so far published for Newfoundland (oldest previous 
date, for bog-bottom peat from Avalon Peninsula, is I(GSC) -4, $8420 \pm 300$, Isotopes I).

\section{GSC-89. Anticosti Island, Quebec}

$12,940 \pm 180$ 10,990 в.c.

Marine shells (Hiatella arctica and Mya truncata; identified by F. J. E. Wagner) from cut bank at $\mathrm{NE}$ corner of airfield, $4 \mathrm{mi} \mathrm{E}$ of Port Menier, western Anticosti Island ( $49^{\circ} 50^{\prime} 20^{\prime \prime} \mathrm{N}$ Lat, $64^{\circ} 16^{\prime} 10^{\prime \prime} \mathrm{W}$ Long). Shells from stratified fine gravel and sand with lenses of clay at alt $180 \mathrm{ft}$ (Locality 3, Bolton and Lee, 1960). Marine limit at $250 \mathrm{ft}$. Coll. 1958 by T. E. Bolton. Comment: date applies to an early (but probably not the earliest) stage of postglacial marine overlap of the island, and is older than dates of comparable materials from Newfoundland to the E (GSC-55, 75, 87, this list) and from the lower part of the St. Lawrence Valley to the W (GSC-61, 63, and 70, this list).

\section{Rivière-du-Loup series, Quebec}

The following dates relate to glacial retreat and marine submergences in the lower St. Lawrence basin, involving the following events (Lee, 1962; Lee, in press).

1. Deglaciation of the Notre Dame Mountains S of the St. Lawrence near Rivière-du-Loup and encroachment of the sea as far up the St. Lawrence Valley as Trois-Pistoles. GSC-102 relates to these penecontemporaneous events. 2. Later reconstitution of the ice margin in the St. Lawrence basin $W$ of TroisPistoles to form the moraine at St. Antonin. GSC-102 and GSC-61 bracket this event.

3. Retreat of ice from the region and progressive uplift of land relative to sea. GSC-102, 63, and 70 relate to uplift "outside" (E of) the moraine at St. Antonin; GSC-61, 69, 68, and 112 relate to uplift behind (W of) the moraine.

\section{GSC-102. Trois-Pistoles}

$12,720 \pm 170$ 10,770 в.c.

Shells of Yoldia arctica from 23 to $27 \mathrm{ft}$ below ground surface in a highway cut made in $1960,2 \mathrm{mi} \mathrm{E}$ of Trois-Pistoles, Quebec $\left(48^{\circ} 07.7^{\prime} \mathrm{N}\right.$ Lat, $69^{\circ} 07.9^{\prime} \mathrm{W}$ Long). Shells from clay overlain by and regionally interbedded with delta sand. The dated material is part of a marine-deltaic-outwash deposit formed when wastage of the ice sheet permitted the sea to penetrate into this part of the St. Lawrence basin (Lee, in press). The delta surface, at alt ca. 550 $\mathrm{ft}$, is believed to mark the local marine limit. Coll. 1962 by H. A. Lee. Comment: sample treatment did not include the usual preliminary leaching of the outer $10 \%$ of the shells with HCl. Sample diluted with dead gas for counting.

\section{GSC-63. St. Epiphane $\quad 11,410 \pm 150$}

Marine pelecypod shells (chiefly Macoma calcarea, Mya truncata and Hiatella arctica) from 10 to $15 \mathrm{ft}$ below surface in a road cut $2.8 \mathrm{mi} \mathrm{N}$ of St. Epiphane, Quebec, near N bank of Rivière Fourche $\left(47^{\circ} 56.3^{\prime} \mathrm{N}\right.$ Lat, $69^{\circ}$ $19.2^{\prime} \mathrm{W}$ Long). Shells collected at alt $310 \mathrm{ft}$ from lens of gray clay at base of "High Terrace sands" overlying "stony red clay" (Lee, 1962). Date is be- 
lieved maximum for the "High Terrace sands" in the vicinity and to represent a marine level at alt $310 \mathrm{ft}$ or slightly higher. Coll. 1961 by H. A. Lee.

\section{GSC-70. L'Isle-Verte, 260 ft}

$10,600 \pm 170$ 8650 в.с.

Marine-pelecypod shells (chiefly Macoma calcarea, Mya truncata, and Hiatella arctica from ca. $25 \mathrm{ft}$ of marine clay (top at alt $260 \mathrm{ft}$ ) in road cut $3.8 \mathrm{mi} \mathrm{S}$ of L'Isle-Verte, Quebec $\left(47^{\circ} 57.7^{\prime} \mathrm{N}\right.$ Lat, $69^{\circ} 19.4^{\prime} \mathrm{W}$ Long). The shells probably represent the Macoma calcarea community (written communication, F. J. E. Wagner). Assuming a depth range of 0 to $60 \mathrm{ft}$ for this community, sample represents a marine level at alt between 260 and $320 \mathrm{ft}$. Coll. 1961 by H. A. Lee. Comment: this date and the dates of the two higher samples listed above (GSC-102, GSC-63) comprise a series that decreases in age with decreasing altitude and provides a rough chronology of emergence in the area "outside" the moraine at St. Antonin.

\section{GSC-61. Rivière-du-Loup}

$10,340 \pm 130$ 8390 в.с.

Shells of Hiatella arctica from gravel pit $0.6 \mathrm{mi} \mathrm{SE}$ of railway station, Rivière-du-Loup, Quebec $\left(47^{\circ} 49.2^{\prime} \mathrm{N}\right.$ Lat, $69^{\circ} 30.8^{\prime} \mathrm{W}$ Long). Shells from clay lens within stratified gravels, ca. $7 \mathrm{ft}$ below top of section. Sample believed to be related to a shoreline at or slightly above the top of the section (alt 330 ft). Coll. 1961 by H. A. Lee. Comment: this date and the dates for the three lower samples listed below provide a rough chronology of emergence in the area formerly covered by the glacial lobe bordered by the moraine at $\mathrm{St}$. Antonin. As would be expected, GSC-61 is younger than GSC-63 and 70, which appear to relate to about the same marine level "outside" the moraine at St. Antonin. The date for GSC-61 quoted above was determined using our standard procedure for extracting $\mathrm{CO}_{2}$ from shells. The following additional dates were determined for the outer and inner parts of a second preparation of the sample, after removal of the outer $10 \%$ of the shells.

$$
\begin{array}{ll}
\text { outer fraction (10 to } 50 \% \text { leach) } & 10,360 \pm 240 \\
\text { inner fraction (50 to } 100 \% \text { leach) } & 10,540 \pm 210
\end{array}
$$

\section{GSC-69. L'Isle-Verte, $180 \mathrm{ft}$}

$9690 \pm 150$ 7740 в.C.

Marine-pelecypod shells (chiefly Hiatella arctica) from gullied surface of marine clay at alt $180 \mathrm{ft}, 2.5 \mathrm{mi} \mathrm{SSW}$ of L'Isle-Verte, Quebec $\left(47^{\circ} 58.1^{\prime} \mathrm{N}\right.$ Lat, $69^{\circ} 19.9^{\prime} \mathrm{W}$ Long). Shells were picked from an assemblage representing the Astarte zone of the Macoma calcarea community (written communication, F. J. E. Wagner). Assuming a depth range of 0 to $60 \mathrm{ft}$ for this community, the sample represents a marine level between alt 180 and $240 \mathrm{ft}$. Date based on one weekend count only. Coll. 1961 by H. A. Lee.

\section{GSC-68. Cacouna}

$9830 \pm 130$ 7880 в.c.

Marine-pelecypod shells (chiefly Macoma calcarea) from stream-eroded surface, in marine clay at alt $53 \mathrm{ft}$, ca. $3.5 \mathrm{mi} \mathrm{NE}$ of Cacouna, Quebec $\left(45^{\circ}\right.$ $57.3^{\prime} \mathrm{N}$ Lat, $69^{\circ} 27.4^{\prime} \mathrm{W}$ Long). Shells represent the Macoma calcarea com- 
munity, possibly the Astarte zone (written communication, F. J. E. Wagner). Assuming a depth range of 0 to $60 \mathrm{ft}$ for this community, the sample should represent a local sealevel between alt 53 and $115 \mathrm{ft}$. However, in view of the geology of the locality, the shells may have been reworked from a higher site. Coll. 1961 by H. A. Lee.

\section{GSC-112. Rivière-des-Vases bog}

$6970 \pm 100$ 5020 в.c.

Peat collected with a piston sampler at $250 \mathrm{~cm}$ depth at bottom of a bog ca. 12 mi NE of Rivière-du-Loup, Quebec ( $47^{\circ} 58^{\prime}$ N Lat, $69^{\circ} 25.5^{\prime}$ W Long). Sample from base of peat overlying sand and gravel at alt ca. $50 \mathrm{ft}$ in an abandoned river channel. Date is minimum for emergence of the site, and hence, for regression of the shore below the 50 -ft level. Coll. 1962 by Jaan Terasmae.

\section{GSC-90. Pembroke, Ontario}

$$
\begin{gathered}
10,870 \pm 130 \\
8920 \text { в.с. }
\end{gathered}
$$

Marine-pelecypod shells from stratified fine sand and silty clay at alt 450 $\mathrm{ft}, 15 \mathrm{ft}$ below surface, in a gravel pit ca. $4 \mathrm{mi}$ SE of Pembroke, Ontario $\left(45^{\circ}\right.$ $47^{\prime} \mathrm{N}$ Lat, $77^{\circ} 03^{\prime} \mathrm{W}$ Long). The shell-bearing deposit occurs as a lens occupying a depression in the top surface of glacio-fluvial gravel and sand, and is overlain in turn by laminated alluvial silty sand and Ottawa River gravel. Coll. 1957 by Jaan Terasmae. Comment: date is assumed to record maximum NW extent of the Champlain Sea up the Ottawa River Valley. It supports the earliest date suggested by Terasmae and Hughes (1960a) for the opening of the North Bay outlet. Sample diluted with dead gas for counting.

\section{GSC-77. Thedford, Ontario $\quad 3100 \pm 80$ \\ 1150 в.C.}

Wood from cut bank, E side of Decker Creek $1.3 \mathrm{mi} \mathrm{N}$ of Thedford, Ontario ( $43^{\circ} 11^{\prime} \mathrm{N} \mathrm{Lat}, 81^{\circ} 51^{\prime} \mathrm{W}$ Long). Sample from base of 3-ft layer of alluvial sand overlying shale bedrock and overlain, in succession, by $2 \mathrm{ft}$ of clayey silt with mollusc shells and $3 \mathrm{ft}$ of silty clay with plant remains. The sand inclosing the wood contains pollen suggesting a warm climate. The deposits probably accumulated at or adjacent to the margin of Lake Huron during the Nipissing phase (top of wood-bearing layer $1 \mathrm{ft}$ below average Nipissing level). Coll. 1960 by Aleksis Dreimanis, Univ. of Western Ontario, London. Comment: $\mathrm{C}^{14}$ age is somewhat younger than expected and may indicate that the deposits accumulated during the later part of the Nipissing phase.

\section{Little Pic River series, Ontario}

Wood and shells from gully 150 yd S of $\mathrm{E}$ end of bridge over Little Pic River on Trans-Canada Highway around N shore of Lake Superior $\left(48^{\circ} 47^{\prime} \mathrm{N}\right.$ Lat, $86^{\circ} 37^{\prime} \mathrm{W}$ Long). The gully exposes $13 \mathrm{ft}$ of clean sand with abundant Sphaerium sulcatum (Lamarck) overlying at least $25 \mathrm{ft}$ of thin bedded clayey silt with disseminated plant materials and two layers that include wood and charred wood. The sloping surface above the gully edge includes another $5 \mathrm{ft}$ of clean sand and, where unmodified by construction work, 1 to $5 \mathrm{ft}$ of windblown sand. Ground alt at $E$ end of bridge $715 \mathrm{ft}$ by altimeter (110 ft above 
Lake Superior) although Farrand (1960) records alt of same terrace as $692 \mathrm{ft}$. The plant-bearing clayey silt is regarded as an estuarine deposit of the ancestral Little Pic River, built into a lake in the Superior basin, at least $90 \mathrm{ft}$ and possibly $110 \mathrm{ft}$ or more above present lake level. The Sphaerium-bearing sands are clearly shoreline deposits of a lake $110 \mathrm{ft}$ above present lake level. Coll. 1961 by V. K. Prest.

\section{GSC-82. Little Pic River, upper wood}

Wood from upper organic-debris layer in well-stratified clayey silt $80 \mathrm{ft}$ above Lake Superior and $8 \mathrm{ft}$ below base of shell-bearing sand.

\section{GSC-103. Little Pic River, lower wood}

Wood from lower organic-debris layer in well-stratified clayey silt $68 \mathrm{ft}$ above Lake Superior and $20 \mathrm{ft}$ below base of shell-bearing sand.

\section{GSC-91. Little Pic River, shells}

$7060 \pm 120$

5110 в.c.

Shells (Sphaerium sulcatum) from central part of 13- to 18-ft mantle of clean sand overlying organic clayey silt, and with surface alt $110 \mathrm{ft}$ above Lake Superior.

General Comment (V.K.P.) : study, by J. Terasmae, of woody layers has revealed a pollen assemblage comparable to that of other parts of $\mathrm{N}$ Ontario for the period 7000 to 5000 yr B.P. The two wood dates (GSC-82 and 103) are in accord with this interpretation but are older than would be expected if the Little Pic River flats represent the Nipissing-Algoma stage as concluded by Farrand (1960). The discrepancy between the shell and wood dates is regarded as due to recycling of older carbonate during the life of the molluscs.

\section{GSC-83. Attawapiskat River, Ontario (sub-till) $>\mathbf{3 5 , 8 0 0}$}

Wood from W bank of Attawapiskat River, Ontario (52 $36^{\prime} \mathrm{N}$ Lat, $86^{\circ}$ $02^{\prime} \mathrm{W}$ Long). At the sample site, till $16 \mathrm{ft}$ thick is underlain successively by horizontally stratified sand and gravel 7 -ft thick and by clay with sand and silt laminae dipping $20^{\circ} \mathrm{SE}$. The sparse wood fragments were collected from clay $5 \mathrm{ft}$ below the erosional surface at the base of the sand-gravel unit. Nearby, clay unit is horizontal. Coll. 1961 by H. H. Bostock for V. K. Prest. Comment: deposits are assumed to represent the same unit as the better-known sub-till plant-bearing beds along the Albany and Missinaibi Rivers 150 and $250 \mathrm{mi}$ SE. Plant materials from the Missinaibi beds have been assigned various "in-

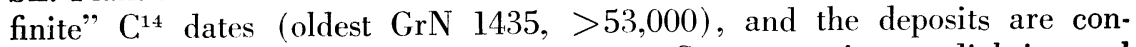
sidered to have accumulated during a post-Sangamon interstadial interval (Terasmae and Hughes, 1960b).

\section{B. Western Canada, general}

\section{GSC-74. Piper Ave., Burnaby, British Columbia $\quad 12,230 \pm 200$}

Shells of Chlamys selected from mixed shells in stony marine clay from spoil of a sewer excavation paralleling the Great Northern Railway on the $N$, 
a few hundred feet $\mathrm{W}$ of Piper Ave., Burnaby, British Columbia $\left(49^{\circ} 15^{\prime} \mathrm{N}\right.$ Lat, $122^{\circ} 56^{\prime} \mathrm{W}$ Long). The clay is at least $7 \mathrm{ft}$ thick, beneath a 14 -ft section of nonmarine sand, peaty sand, peat, and lenses of gravel. Alt of top of clay $39 \mathrm{ft}$; level of dated shells within the clay is not known. Coll. 1961 by W. H. Mathews, G. E. Rouse, and L. V. Hills; subm. by W. H. Mathews, Univ. of British Columbia, Vancouver. Comment: it had been hoped that these shells, coupled with the date of overlying peat would date the emergence of the site. However, in view of other dates from the vicinity, and particularly that of shells from alt $440 \mathrm{ft}$ on nearby Burnaby Mountain (L-391C, 11,900 \pm 300 , written communication J. E. Armstrong), this sample relates to an early phase of marine submergence when the site was still depressed well below sealevel. Date based on one weekend count only.

\section{GSC-64. North Delta, British Columbia $\quad 12,460 \pm 170$ 10,510 в.c.}

Shells of Serpula and of various marine pelecypods from Linton gravel pit, North Delta, Lower Fraser Valley, British Columbia $\left(49^{\circ} 08^{\prime} \mathrm{N}\right.$ Lat, $122^{\circ} 55^{\prime}$ W Long). Shells from stony, silty sand overlain by till-like material, glaciomarine stony, clayey silt, and beach gravel. The shell-bearing layer rests on the eroded surface of thick horizontal sand similar to the sub-till Quadra sediments. Coll. 1961 by J. E. Armstrong. Comment: the shell-bearing material is interpreted as being glacio-marine, accumulated during wastage of the last (Vashon?) ice sheet. The date is compatible with this interpretation and compares favorably with I(GSC) $-248,12,800 \pm 175$, Isotopes II. Date based on one weekend count only.

\section{GSC-80. Nanaimo, Vancouver Island $\quad 12,420 \pm 150$}

Marine shells and shell fragments (chiefly Mya, Serripes, and Mytilus) from an excavation at Dept. of Natl. Defense property, Nanaimo, British Columbia $\left(49^{\circ} 09^{\prime} 00^{\prime \prime} \mathrm{N}\right.$ Lat, $123^{\circ} 58^{\prime} 10^{\prime \prime} \mathrm{W}$ Long). Shells from silty, stony clay, max $10 \mathrm{ft}$ thick, underlain by till and overlain by beach gravel. Site is $354 \mathrm{ft}$ above sealevel and ca. $100 \mathrm{ft}$ below the marine limit. Coll. 1961 by $\mathrm{E}$. C. Halstead. Comment: the dated material accumulated during the early part of the interval of postglacial marine submergence when the shore was still less than $100 \mathrm{ft}$ below its earliest highest level. The $\mathrm{C}^{14}$ age is a few hundred years younger than expected from other dates from the region, particularly L-391D, wood, 12,150 \pm 250 , and L-391E, Marine shells, 12,350 \pm 250 (Lamont V) from a delta $20 \mathrm{mi} \mathrm{NW}$ and only $170 \mathrm{ft}$ above sealevel.

\section{GSC-79. Kamloops, British Columbia $\quad 25,200 \pm 460$ 23,250 в.c.}

Fresh water shells (Margaretifera margaretifera var. falcata, Anodonta nuttalliana: id. by F. J. E. Wagner) from borrow pit at the base of the $\mathrm{S}$ wall of Thompson River Valley ca. $5 \mathrm{mi}$ W of Kamloops, British Columbia $\left(50^{\circ}\right.$ $41^{\prime} 20^{\prime \prime} \mathrm{N}$ Lat, $120^{\circ} 26^{\prime} 30^{\prime \prime} \mathrm{W}$ Long). Shells are from clayey silty sand, $35 \mathrm{ft}$ thick, overlain by recent alluvium and underlain by silty clay. Deposits similar to the clayey silty sand and silty clay are exposed beneath till at various places. The shell-bearing deposit accumulated in a lake occupying the Kamloops Lake 
basin during an interstadial or interglacial interval prior to the last (classical Wisconsin) glaciation. Coll. 1961 by R. J. Fulton. Comment: date agrees with the geologic interpretation (above) based on field evidence. It also supports the tentative inference that the deposits are equivalent to the Quadra sediments in the Strait of Georgia region (see dates below).

\section{Interstadial deposits, Georgia Depression, SW British Columbia}

The following dates, from the lowlands bordering the Strait of Georgia, British Columbia, apply to various nonglacial, sub-till deposits, including the widespread interstadial Quadra sediments. Dating was undertaken to help distinguish the Quadra and its equivalents from older (and perhaps younger) sub-till nonglacial deposits. Plant materials known to belong to the Quadra so far have yielded only finite dates ranging from 24,000 to $36,000 \mathrm{yr}$ (L-221A, L-221B, L-424B, L-424C, L-424E, Lamont V; L-455B, L-502, Lamont VII; GSC-53, 95, 108, 109, this list). Marine shells from the basal part of the Quadra, however, have yielded infinite dates (L-475A, L-475B, Lamont VII). Plant materials that probably belong in the basal part of the Quadra at two localities have likewise yielded infinite dates (GSC-81, 94, this list).

\section{GSC-60. East Delta, Lower Fraser Valley}

Wood from Kiewet gravel pit, East Delta, Lower Fraser Valley, British Columbia $\left(49^{\circ} 07^{\prime} \mathrm{N}\right.$ Lat, $122^{\circ} 54^{\prime} \mathrm{W}$ Long). Sample from $25-\mathrm{ft}$ section of horizontally stratified silty sand and sand resting unconformably on gravel and overlain by 3 to $5 \mathrm{ft}$ of stony laminated silt, 5 to $10 \mathrm{ft}$ of till, and $5 \mathrm{ft}$ of beach gravel. Coll. 1961 by J. E. Armstrong. Comment: see GSC-62.

\section{GSC-62. Knight Road, Lower Fraser Valley}

\section{$>39,000$}

Wood from Knight Road gravel pit, South Westminster, Lower Fraser Valley, British Columbia $\left(49^{\circ} 10^{\prime} \mathrm{N}\right.$ Lat, $122^{\circ} 55^{\prime} \mathrm{W}$ Long). Sample from a 1- to 5 -ft layer of clayey silty sand beneath a few feet of till and beach gravel. The wood-bearing material rests on stratified silt containing channel-like bodies of gravel. Comment: this sample and GSC-60 are from two of the many small exposures of sub-till stratified deposits along the margin of the Surrey Upland. Such deposits are widely distributed beneath the upland, but little is known of their stratigraphy and none are known to be equivalent to the Quadra sediments. In view of the $\mathrm{C}^{14}$ dates, the sampled materials may possibly be older than the Quadra sediments.

\section{GSC-108. Spanish Banks, Point Grey \\ $24,500 \pm 500$ 22,550 в.c.}

Wood from Quadra sand $50 \mathrm{ft}$ above sealevel in sea cliff at Spanish Banks, Point Grey (Vancouver Metropolitan area), British Columbia $\left(49^{\circ} 17^{\prime} \mathrm{N}\right.$ Lat, $123^{\circ} 13^{\prime} \mathrm{W}$ Long). Sample site ca. $300 \mathrm{ft}$ from L-502 (24,400 \pm 900 , Lamont VII) and at about the same stratigraphic level. Coll. 1962 by J. E. Armstrong. Comment: this additional sample from the type section of the Quadra was dated to provide confirmation of the age of the unit, because of uncertainties arising from the infinite date of GSC-81 (this list). 


\section{GSC-109. Wreck Beach, Point Grey}

Peat from stratified silt and sand $25 \mathrm{ft}$ above sealevel on sea cliff at Wreck Beach, Point Grey (Vancouver Metropolitan area), British Columbia $\left(49^{\circ} 16^{\prime}\right.$ $\mathrm{N}$ Lat, $123^{\circ} 15^{\prime} \mathrm{W}$ Long). Site ca. $2 \mathrm{mi}$ S of GSC-108. Coll. 1962 by J. E. Armstrong. Comment: date supports assignment to the Quadra sediments. Date based on a single count.

\section{GSC-81. Highbury Tunnel, Vancouver}

Peat from bore-hole 30-0-9, Highbury St. Sewage Tunnel, Vancouver (City), British Columbia $\left(49^{\circ} 15^{\prime} \mathrm{N}\right.$ Lat, $123^{\circ} 11^{\prime} \mathrm{W}$ Long). Sample from depth between 144 and $147 \mathrm{ft}$ (91 ft above sealevel) at base of sub-till sands believed to belong in the Quadra sediments. Coll. 1962 by J. E. Armstrong. Comment: sample was expected to yield a typical Quadra age of ca. 25,000 to $30,000 \mathrm{yr}$. The inflnite date may possibly be compatible with the inference that the sample belongs at the base of the Quadra (see introduction to this group of dates and L-475A, L-475B, Lamont VII). NaOH-leach was omitted from pretreatment of the sample.

\section{GSC-93. Lynn Canyon, North Vancouver}

$$
33,200 \pm \underset{1800}{2300}
$$

\section{1,250 в.c.}

Wood from peat bed $2 \mathrm{ft}$ thick near base of Canyon wall, Lynn Creek, North Vancouver, British Columbia $\left(49^{\circ} 21^{\prime} \mathrm{N}\right.$ Lat, $123^{\circ} 02^{\prime} \mathrm{W}$ Long). The peat is underlain by till and lies at the base of more than $150 \mathrm{ft}$ of sand and gravel believed to be equivalent to and younger than the Quadra sediments. Coll. 1960 by J. E. Armstrong. Comment: the $\mathrm{C}^{14}$ age supports the inference that the sand and gravel unit is in part equivalent to the Quadra sediments. It also suggests correlation with the upper of two sand-gravel units (with basal peat) lying between three till sheets, exposed in a nearby highway cut (see I(GSC) -214, 32,200 \pm 3300 , Isotopes II) .

\section{GSC-36. Tupper School, Vancouver $>\mathbf{3 8 , 1 0 0}$}

Wood from a peat bed exposed in an excavation at the Sir Charles Tupper School, 23rd and St. George St., Vancouver (City), British Columbia $\left(49^{\circ} 15^{\prime}\right.$ $\mathrm{N}$ Lat, $123^{\circ} 06^{\prime} \mathrm{W}$ Long). Sample from one of several peaty beds within clays and sands ca. $10 \mathrm{ft}$ thick separated from underlying Tertiary sandstone by ca. $1 \mathrm{ft}$ of till and overlain by 5 to $10 \mathrm{ft}$ of Surrey (Vashon) till and Newton glacio-marine deposits. Coll. 1958 by J. E. Armstrong. Comment: relation of this sub-till deposit to others in the region remains unknown, but in view of the $\mathrm{C}^{14}$ date it may be older than the Quadra sediments.

\section{GSC-58. Upper Campbell, Vancouver Island $\quad \mathbf{2 5 , 0 0 0} \pm 400$

Wood (base of tree $2 \mathrm{in}$. diam.) ca. $3 \mathrm{ft}$ above the base of a $15-\mathrm{ft}$ cut bank on SE side of logging road immediately above Buttle Lake Road, E side of Upper Campbell Lake, Vancouver Island, British Columbia, $1000 \mathrm{ft} \mathrm{NE}$ of Berry Creek and alt ca. $780 \mathrm{ft}\left(49^{\circ} 56^{\prime} 50^{\prime \prime} \mathrm{N}\right.$ Lat, $125^{\circ} 35^{\prime} 50^{\prime \prime} \mathrm{W}$ Long). Sample from a layer of sticks in the bottom few inches of a 7 - $\mathrm{ft}$ section of in- 
distinctly laminated silt, clay, and fine sand containing peaty partings. Beneath the wood layer is 3-to-6 in. of peaty silt resting on and penetrating downward into angular gravel which directly overlies bedrock at one end of the exposure. This sequence of deposits forms an isolated pocket, covered by slope debris, at the bottom of the steep wall of the U-shaped valley. The deposits appear to belong at the base of several hundred feet of horizontal sands and silts capped by till in the re-entrant in the valley wall occupied by Berry Creek. These and other isolated bodies of similar materials in the valley and on the lowland to the $\mathrm{NE}$ are believed to be remnants of formerly extensive fluvial and lacustrine deposits that have survived glaciation. The $\mathrm{C}^{14}$ date supports correlation with the Quadra sediments. Coll. 1958 by J. G. Fyles.

\section{GSC-96. Buttle Lake, Vancouver Island $\quad 25,190 \pm 470$}

Wood from a small tree (Abies) exposed in a road cut, $\mathrm{E}$ bank of Campbell River at upstream end of U-bend in river $1 \mathrm{mi} \mathrm{N}$ of Buttle Lake dam, Vancouver Island, British Columbia $\left(49^{\circ} 51^{\prime} 05^{\prime \prime} \mathrm{N}\right.$ Lat, $125^{\circ} 37^{\prime} 20^{\prime \prime} \mathrm{W}$ Long); collected from $1.5 \mathrm{ft}$ of laminated silt with organic layers, overlain by ca. $20 \mathrm{ft}$ of till and gravel. The plant-bearing material is separated from the steep bedrock wall of the U-shaped valley by a few inches of angular gravel resembling sliderock. The deposit is believed to be a remnant of the same stratigraphic unit as GSC-58 (see above) collected ca. $7 \mathrm{mi} \mathrm{N}$ in the same valley. Date supports correlation with the Quadra sediments. Coll. 1958 by J. G. Fyles.

\section{Willemar Bluff series, Vancouver Island}

Wood from two levels within the sand unit of the Quadra sediments on the sea cliff at Willemar Bluff $1.5 \mathrm{mi} \mathrm{E}$ of Comox, Vancouver Island, British Columbia $\left(49^{\circ} 40^{\prime} 10^{\prime \prime} \mathrm{N}\right.$ Lat, $124^{\circ} 53^{\prime} 50^{\prime \prime} \mathrm{W}$ Long). Coll. 1957 by J. G. Fyles.

GSC-53. Willemar Bluff, upper wood $\quad 26,100 \pm 400$

$$
\text { GSC-53. Willemar Bluff, upper wood 24,150 в.c. }
$$

Water-worn fragments of wood from driftwood lens in sand $118 \mathrm{ft}$ above high-tide level.

\section{GSC-95. Willemar Bluff, lower wood}

$28,800 \pm 740$

Flattened wood up to $0.5 \mathrm{in}$. diameter from 3 -in. bed of silty peat $70 \mathrm{ft}$ above high tide.

General comment: these two dates are in correct stratigraphic sequence in relation to each other and also in relation to L-424B, L-424C, and L-424E $(30,200 \pm 1300,29,300 \pm 1400,30,000 \pm 1200$, respectively; Lamont V) for wood from the thin silt-gravel unit of the Quadra sediments beneath the sand unit on Denman Island $5 \mathrm{mi}$ to the SE (Fyles, 1960). Despite overlap of the age range of the three Lamont dates with that of GSC-95, the correct stratigraphic arrangement of the dates is taken as evidence supporting the validity of the finite $\mathrm{C}^{14}$ ages assigned to plant materials from the sand unit and the silt-gravel unit of the Quadra (see discussion of Quadra beds series, 
Lamont V). The sequence of dates also points up the disparity between these finite dates and the infinite date assigned to shells from the immediately underlying marine stony clay (L-475A, Lamont VII; see also GSC-94, this list).

\section{GSC-78. Wilfred Creek, Vancouver Island}

Dense peat from a fresh landslide scar on the wooded NW wall of Wilfred Creek valley, 1.3 mi upstream from the $\mathrm{E}$ and $\mathrm{N}$ Railway, near Fanny Bay, Vancouver Island, British Columbia (49 $29^{\prime} 25^{\prime \prime} \mathrm{N}$ Lat, $124^{\circ} 50^{\prime} 00^{\prime \prime} \mathrm{W}$ Long). The peat layer, $0.5 \mathrm{in}$. thick, lies within $20 \mathrm{ft}$ of laminated silt, sand, and pebble gravel containing oxidized plant remains. These materials are underlain by thick bouldery gravel and overlain by $150 \mathrm{ft}$ of pebble gravel and sand capped by a few feet of till. These sub-till deposits, which underlie an area $5 \mathrm{mi}$ long and up to $2 \mathrm{mi}$ wide, differ somewhat in lithology from the Quadra sediments. From geologic evidence, they may be either a facies variant of the Quadra or an entirely different unit; on the basis of this date they may be older than the Quadra. Coll. 1956 by J. G. Fyles.

\section{GSC-99. Chef Creek, Vancouver Island}

Wood from cut bank, S side of Island Highway $0.25 \mathrm{mi} \mathrm{E}$ of Chef Creek, near Deep Bay, Vancouver Island, British Columbia $\left(49^{\circ} 27^{\prime} \mathrm{N}\right.$ Lat, $124^{\circ} 45^{\prime}$ W Long). Sample from an inter-till section $10 \mathrm{ft}$ thick in which fine sand and silt containing wood and mats of plant detritus grade laterally into medium to coarse sand and into shell-bearing marine clay beneath the sand. These deposits are inferred to form the base of the Quadra sediments at this locality (Fyles, 1963, p. 26, 27) and have yielded abundant pollen suggesting forest comparable to that growing today in the wetter parts of Vancouver Island (Fyles, 1963, p. 28). Coll. 1951 by J. G. Fyles. Comment: this date raises the same problem regarding the age range of the Quadra interval as other samples such as GSC-81 and GSC-94 (this list). In spite of the infinite date, the collector still tentatively assigns the deposits to the Quadra sediments, but admits the possibility that they are distinct from and older than the Quadra.

\section{GSC-84. Cordova Bay, Vancouver Island \\ $22,600 \pm 300$ 20,650 в.c.}

Plant fibers concentrated from organic silt $40 \mathrm{ft}$ above the beach on a sea cliff, SE part of Cordova Bay, near Victoria, Vancouver Island, British Columbia ( $48^{\circ} 29^{\prime} 40^{\prime \prime} \mathrm{N}$ Lat, $123^{\circ} 19^{\prime} 10^{\prime \prime} \mathrm{W}$ Long). The sampled bed lies within a $50-\mathrm{ft}$ section of organic silt and fine sand overlain by $80 \mathrm{ft}$ of sand and underlain by thin gravel and marine stony silt. These nonglacial strata lie beneath the surface (Vashon) till and belong to a widespread interstadial unit similar in lithology and occurrence to the Quadra sediments. At the E end of Cordova Bay, till beneath these deposits is underlain by a second succession of rather similar nonglacial deposits overlying a still older till. Coll. 1958 by J. G. Fyles. Comment: date suggests correlation of the widespread upper interstadial unit on SW Vancouver Island with the Quadra sediments. This is the youngest date so far assigned to sub-till deposits in the region. See also comments concerning GSC-94, below. 
Wood from the base of a wave-cut cliff on the $\mathrm{E}$ side of Sidney Island, Haro Strait, British Columbia ( $48^{\circ} 38^{\prime} 40^{\prime \prime}$ N Lat, $123^{\circ} 19^{\prime} 40^{\prime \prime}$ W Long), a few tens of feet $\mathrm{S}$ of base of spit at $\mathrm{N}$ end of island. The small flattened pieces of wood were collected from a 1 -ft bed of peaty silt in a shallow pit at the inshore margin of the beach. The peaty bed is underlain by fine sand and overlain by $10 \mathrm{ft}$ of sand capped by till. The same sub-till deposits are exposed in many places (thickness up to $80 \mathrm{ft}$ ) along the $E$ shore of the island for $2 \mathrm{mi}$ $\mathrm{S}$ of the sample site. Coll. 1958 by J. G. Fyles. Comment: the sub-till deposits to which this date applies are characteristic of the widespread sandy upper interstadial deposits of the SW Vancouver Island region. The date supports correlation of this unit with the Quadra sediments (see GSC-84).

\section{GSC-94. Cowichan Head, Vancouver Island}

Wood collected $35 \mathrm{ft}$ above the beach on a sea cliff at Cowichan Head, Saanich Peninsula, Vancouver Island, British Columbia $\left(48^{\circ} 34^{\prime} \mathrm{N}\right.$ Lat, $123^{\circ}$ $22^{\prime} \mathrm{W}$ Long). Sample from a pocket of driftwood within $7 \mathrm{ft}$ of pebbly fine silty sand containing marine shells. This material grades upward into sands and sandy gravels $80 \mathrm{ft}$ thick capped by till, and is underlain by ca. $10 \mathrm{ft}$ of stony marine silt and clay. This sequence of strata beneath till is believed to be equivalent to the upper inter-till unit at Cordova Bay ca. $5 \mathrm{mi}$ to the $\mathrm{S}$ (see GSC-84, above). Coll. 1958 by J. G. Fyles. Comment: wood from stony marine clay at Cowichan Head at a slightly lower level than this sample has been dated as $>42,000$ (L-514C, Lamont VII). Shells from the stony marine clay have yielded an age of $35,000 \pm 1600$ (L-514D, Lamont VII) but the author of the Lamont date list suggests that the shells are contaminated. If the sands above the wood- and shell-bearing deposits belong to the same stratigraphic unit as GSC-84 and 59, as maintained by the collector, then the wood- and shell-bearing deposits are much older than the overlying sands. This age difference is analagous to that between comparable units of the Quadra sediments (see L-475A, L-475B, Lamont VII and various entries in this list above).

\section{Northern Canada}

\section{Hunker Creek series, Yukon}

Wood from frozen silty peat in a fresh cut-bank exposure in right bank of Hunker Creek, at the mouth of Last Chance Creek, Klondike Dist., Yukon (64 ${ }^{\circ}$ $01^{\prime} \mathrm{N}$ Lat, $139^{\circ} 06^{\prime} \mathrm{W}$ Long). Samples were collected from a $20-\mathrm{ft}$ bed of woody, silty peat underlain by $6 \mathrm{ft}$ of silt containing plant detritus down to the creek. Sand and gravel seams occur in the base of the peat unit. Coll. 1961 by Jaan Terasmae and O. L. Hughes.

GSC-57. Hunker Creek

$8660 \pm 140$ 6710 в.с.

Wood from woody silty peat unit at depth $16 \mathrm{ft}$. Pollen is poorly preserved; vegetation was similar to the present Boreal forest. 
GSC-73. Hunker Creek

Wood from base of woody silty peat unit at a depth of $20 \mathrm{ft}$.

General comment (O.L.H.) : the change from uniform silt (lower part of this section) to woody silty peat containing sand and gravel seams (upper part of this section) represents a significant change in sedimentation. The age of GSC-73, immediately above this break, is almost identical with the $9510 \pm$ $220 \mathrm{yr}$ age (I(GSC)-196, Isotopes II) obtained for organic silt underlain by silty gravel with mammal bones, and capped by woody peat, from Fant and Norbeck placer pit $4.5 \mathrm{mi}$ upstream on Hunker Creek. Silt in the lowermost $6 \mathrm{ft}$ of the present section is tentatively correlated with silt that lies beneath the bone-bearing gravel at Fant and Norbeck placer pit, and that has yielded wood dated at $>35,000$, (I(GSC)-181, Isotopes II) .

\section{GSC-66. Hay Ranch Bog, Yukon $280 \pm 120$ \\ A.D. 1670}

Peat, 12 in. below surface, in an extensive muskeg along Klondike River ca. $15 \mathrm{mi} \mathrm{E}$ of Dawson, Yukon ( $64^{\circ} 03^{\prime} \mathrm{N}$ Lat, $139^{\circ} 00^{\prime} \mathrm{W}$ Long). Exposure in a highway borrow pit shows alluvial gravel at base, overlain by thin sand layer (2 to $5 \mathrm{in}$.) and 6 to $8 \mathrm{in}$. of decomposed woody peat and $12 \mathrm{in.}$ of fresh Sphagnum peat. Coll. 1961 by Jaan Terasmae. Comment: the sudden change in the peat sequence is accompanied by an increase of black spruce, pine, and ericaceous pollen and Sphagnum spores possibly reflecting climatic change. Sample was treated with cold (rather than hot) $\mathrm{NaOH}$ and $\mathrm{HCl}$.

\section{Hart Lake marl series, Yukon}

\section{GSC-67. Carbonate fraction}

\section{GSC-67-2. Organic residue}

Marl from ca. $6 \mathrm{ft}$ below original surface, exposed on the face of a frostheaved block in an area of palsa mounds, NW end of Hart Lake, Yukon $\left(64^{\circ}\right.$ $37^{\prime} \mathrm{N}$ Lat, $135^{\circ} 10^{\prime} \mathrm{W}$ Long). The marl is overlain by 2 to $12 \mathrm{in}$. of peat. Hart Lake, in which the marl was deposited, is impounded by a moraine ridge at its $\mathrm{NW}$ end. The age is minimum for retreat of a valley glacier from the moraine. Coll. 1961, by Peter Vernon; subm. by O. L. Hughes. Comment (O.L.H.) : the age is compatible with approximate correlation of the moraine with late Wisconsin moraines of the region, but does not rule out correlation with considerably older moraines of the same region. Carbonate rocks are abundant in the area; the greater apparent age of the inorganic fraction may be attributed to hard water effect.

\section{GSC-97. Peel River, Yukon}

$8780 \pm 160$ 6830 в.c.

Wood from $6.5 \mathrm{ft}$ below surface in the backwall of a flow slide, $\mathrm{S}$ bank of Peel River $3.5 \mathrm{mi}$ downstream from mouth of Wind River, Bonnet Plume Basin, Yukon ( $65^{\circ} 52^{\prime} \mathrm{N}$ Lat, $135^{\circ} 08^{\prime} \mathrm{W}$ Long). Peel River at this point is intrenched through $230 \mathrm{ft}$ of Pleistocene and $135 \mathrm{ft}$ of Tertiary sediments. The 
Pleistocene stratigraphy, typical of that exposed along lower Wind and Bonnet Plume Rivers, and Peel River between the mouths of the former, consists from the bottom up of gravel, glacio-lacustrine clay, till, and glacio-lacustrine clay, capped by woody silt and peat. Coll. 1962 by O. L. Hughes. Comment: the age of the sample, from near the base of woody silt and peat at the top of the section, is minimum for drainage of a glacial lake which discharged northward via Eagle River during retreat of a lobe of Laurentide ice which earlier had pushed westward at least to $136^{\circ} 20^{\prime} \mathrm{W}$ Long. Drainage may have occurred considerably before burial of the wood. Date based on one weekend count only.

\section{GSC-54. Mackenzie River Delta}

$6900 \pm 110$

4950 в.c.

Wood from depth $125.5 \mathrm{ft}$ in bore-hole MD2, Natl. Res. Council permafrost borings $5 \mathrm{mi} \mathrm{SW}$ of Inuvik, Dist. of Mackenzie, Northwest Territories $\left(68^{\circ} 18^{\prime} \mathrm{N} \mathrm{Lat}, 133^{\circ} 50^{\prime} \mathrm{W}\right.$ Long), on the delta plain of Mackenzie River. The borings encountered (top to bottom) $100 \mathrm{ft}$ of thinly stratified sandy silt with layers of woody plant material throughout, $80 \mathrm{ft}$ of sand with plant layers (dated sample), spaced at irregular intervals throughout, and $60 \mathrm{ft}$ of dense clay with no visible organic remains and with stones in the lowermost few feet. Microorganisms from various woody layers represent fresh water rather than marine conditions. Coll. 1961 by G. H. Johnston, Div. of Building Res., Natl. Res. Council, Ottawa, Canada. Comment: evidently the plant-bearing esturaine-deltaic sand and silt began to accumulate several thousand years after retreat of the last (classical Wisconsin?) Laurentide Ice Sheet from the site, which is close to ice-sheet limit. $\mathrm{NaOH}$-leach was omitted from pretreatment of the sample.

\section{GSC-34. Nicholson Peninsula}

$>\mathbf{3 5 , 2 0 0}$

Wood collected $20 \mathrm{ft}$ below top of $120-\mathrm{ft}$ sea cliff at $\mathrm{N}$ end of Nicholson Peninsula, Dist. of Mackenzie, Northwest Territories ( $69^{\circ} 56^{\prime} \mathrm{N}$ Lat, $128^{\circ} 55^{\prime}$ W Long). Sample from deformed sand containing numerous flattened logs up to 5 in. in diam. Shells of Yoldia arctica (id. by F. J. E. Wagner), are present in underlying clay, and fragments of mammoth (?) tusk apparently washed out of the cliff are present on the beach. The wood-bearing strata are believed to have been deformed by glacial ice thrust (Mackay, 1956) and therefore to be older than the last glacial invasion of the region. Coll. 1960 by J. Ross Mackay, Univ. of British Columbia; subm. by the Geog. Br., Dept. of Mines and Tech. Surveys, Ottawa, Canada.

\section{GSC-32. Arrowsmith River (560 ft) Peat}

$4530 \pm 120$

2580 B.C.

Woody plant material at alt $560 \mathrm{ft}$ on W side of Arrowsmith River $25 \mathrm{mi}$ from Pelly Bay $\left(68^{\circ} 05^{\prime} \mathrm{N}\right.$ Lat, $90^{\circ} 09^{\prime} \mathrm{W}$ Long). Sample from bottom of section of several feet of peat lying on marine silt. Coll. 1960 by M. Tremblay for B. G. Craig. Comment (B.G.C.) : this sample and shell sample GSC-47 $(8700 \pm 120$, GSC I $)$ were dated to bracket time of emergence of the site. However, date of this sarmie suggests emergence long before accumulation of the peat. Sample treated with cold (rather than hot) $\mathrm{NaOH}$ and $\mathrm{HCl}$. 
GSC-65. White Point, Ellesmere Island

Marine pelecypod (mostly Hiatella arctica) shells and fragments collected 2 mi inland from Nansen Sound $5 \mathrm{mi} \mathrm{S}$ of White Point, Ellesmere Island, Northwest Territories ( $81^{\circ} 07^{\prime} \mathrm{N}$ Lat, $90^{\circ} 07^{\prime} \mathrm{W}$ Long). Shells from slumped bank of modern stream, alt ca. $400 \mathrm{ft}$, ca. $150 \mathrm{ft}$ above the highest clearly defined marine features. The shells occur in stratified gravel, sand, and silt containing thin organic layers. On the basis of poor exposures, the shell-bearing material is inferred to underlie till. Coll. 1961 by J. G. Fyles. Comment: date is based on three counts. As the shells were collected from the ground surface where they could readily be contaminated with the minute amount of modern carbon required to give them the measured activity, the date should probably be regarded as minimum.

\section{GSC-105. Oobloyah Bay, Ellesmere Island $\quad 4190 \pm 130$ \\ 2240 B.C.}

Peat collected a few hundred feet from the ice cliff at the $W$ side of a piedmont glacier tongue blocking the head of a valley $10 \mathrm{mi} \mathrm{E}$ of the head of Oobloyah Bay, Ellesmere Island, Northwest Territories (80 $54^{\prime} \mathrm{N}$ Lat, $82^{\circ} 17^{\prime}$ W Long). Sample from the bottom of a stream bank cut into peat that has accumulated on the valley floor upstream from a cross-valley moraine $1 / 3 \mathrm{mi} \mathrm{W}$ of the present ice cliff. The sample was collected ca. $6 \mathrm{ft}$ below ground but the true stratigraphic depth is probably less than this figure. The base of the peat was not exposed at the sample site but elsewhere the peat rests on gravel at depths of 1 to $3 \mathrm{ft}$. Coll. 1961 by J. G. Fyles. Comment: date is minimum for the moraine. Moreover, the piedmont-glacier lobe is now as extensive as, and probably more extensive than at any time during the last $4000 \mathrm{yr}$. Sample mixed with dead gas for counting. Date based on one count.

\section{ARCHAEOLOGICAL SAMPLES}

\section{GSC-85. Pic River Site, Ontario}

$$
\begin{array}{r}
1000 \\
\text { A.D. } 950
\end{array}
$$

Charcoal from Pic River site, W bank of mouth of Pic River, $\mathrm{N}$ shore of Lake Superior, Ontario (48 $36^{\prime} \mathrm{N}$ Lat, 86 $16^{\prime} \mathrm{W}$ Long). Sample from Stratum 3, Sq OEIN2, depth 9 in. It relates to a pure component of the Blackduck Focus which played a major role in the Late Woodland culture history of N Minnesota, NW Ontario, and SE Manitoba. Coll. 1960 by J. N. Emerson; subm. by J. V. Wright, Nat. Mus. of Canada, Ottawa.

\section{GSC-86. Malcolm Site, Ontario \\ $3850 \pm 90$}

Cor the Malcolm site (Dailey and Wright, 1955) $3 \mathrm{mi} \mathrm{W}$ of Cornwall, Ontario, in Lot 23, Concesion 1, Cornwall Twp., Stormont Co. (45 $01^{\prime} \mathrm{N}$ Lat, $74^{\circ} 49^{\prime} \mathrm{W}$ Long). Sample from Pit 11, Trench 1, Sector 15, depth 22 to 25 in. below surface. Coll. 1954 by J. V. Wright. Comment: charcoal came from one of seven large pits devoid of cultural material. The date indi- 
cates pits are much older than the Point Peninsula 4, Focus material mantling the site and suggests they belong to the Archaic period, even though diagnostic Archaic traits were lacking.

Date lists:

GSC I Dyck and Fyles, 1962

Isotopes I Walton, Trautman, and Friend, 1961

Isotopes II Trautman and Walton, 1962

Lamont II Kulp and others, 1952

Lamont V Olson and Broecker, 1959

Lamont VII Olson and Broecker, 1961

USGS IV Rubin and Alexander, 1958

Armstrong, J. E., 1957, Surficial geology of New Westminster map-area, British Columbia: Canada, Geol. Survey Paper 57-5, 25 p.

Bolton, T. E., and Lee, P. K., 1960, Post-glacial marine overlap of Anticosti Island, Quebec: Canada Geol. Assoc. Proc., v. 12, p. 67-78.

Dailey, R. C., and Wright, J. V., 1955, The Malcolm Site, a late stage of the Middle Point Peninsula Culture in eastern Ontario: Royal Canadian Inst., Trans. v. 31, pt. 1, p. 3-23.

Deevey, E. S., 1951, Late-glacial and postglacial pollen diagrams from Maine: Am. Jour. Sci., v. 249, p. 177-207.

Dyck, Willy, and Fyles, J. G., 1962, Geological Survey of Canada radiocarbon dates I: Radiocarbon, v. 4 , p. $13-26$.

Farrand, W. R., 1960, Former shorelines in western and northern Lake Superior basin: Unpubl. PhD. dissertation, Univ. of Michigan, Ann Arbor, Michigan, $226 \mathrm{p}$.

Fyles, J. G., 1960, Surficial geology, Courtenay, British Columbia: Canada, Geol. Survey Map 32-1960.

1963, Surficial geology of Horne Lake and Parksville map-areas, Vancouver Island, British Columbia: Canada Geol. Survey Mem. 318.

Hughes, O. L., 1957, Surficial geology of Shubenacadie map-area, Nova Scotia: Canada, Geol. Survey Map 6-1956.

Kulp, J. L., Tryon, L. E., Eckelman, W. R., and Snell, W. A., 1952, Lamont natural radiocarbon measurements, II: Science, v. 116, p. 409-414.

Lee, H. A., in press, Pleistocene glacial-marine relations, Trois-Pistoles, Quebec: Geol. Soc. America, Abstracts for 1962.

1962, Surficial geology of Rivière-du-Loup-Trois-Pistoles area, Quebec: Canada, Geol. Survey Paper 61-32, 2 p. and map.

Mackay, J. R., 1956, Deformation by glacier-ice at Nicholson Peninsula: Arctic, v. 9, p. 218-228.

Ogden, J. G., 1959, A late-glacial pollen sequence from Martha's Vineyard, Massachusetts: Am. Jour. Sci., v. 257, p. 366-381.

Olson, E. A., and Broecker, W. S., 1959, Lamont natural radiocarbon measurements V: Am. Jour. Sci. Radioc. Supp., v. 1, p. 1-28. $141-175$.

Rubin, Meyer, and Alexander, Corinne, 1958, U. S. Geological Surey radio IV: Science, v. 127, p. 1476-1487.

Stockwell, C. H., 1957, Geology and economic minerals of Canada: Canada, Geol. Survey, Ec. Geol. Ser. no. 1, 4th ed., 517 p.

Terasmae, Jaan, and Hughes, O. L., 1960a, Glacial retreat in the North Bay area, Ontario: Science, v. 131, p. 1444-1446.

1960b, A palynological and geological study of Pleistocene deposits in the James Bay Lowlands, Ontario: Canada, Geol. Survey Bull. 62, 15 p.

Trautman, M. A., and Walton, Alan, 1962, Isotopes, Inc. radiocarbon measurements II: Radiocarbon, v. 4, p. 35-42.

Walton, Alan, Trautman, M. A., and Friend, J. P., 1961, Isotopes, Inc. radiocarbon measurements I: Radiocarbon, v. 3, p. 47-59. 